\title{
Aikuisten päivähoitoa
}

\author{
Työllisyyskursseja pidetään usein työttömien "päivähoitona" ja työ \\ markkinapelissä epäonnistuneiden vaihtoehtona. Tämä kuva elää yhä, \\ vaikka entistä useammat eri sosioekonomisista ryhmistä osallistuvat \\ koulutukseen. Missä määrin käsitys on oikeutettu?
}

\begin{abstract}
Suomen työmarkkinat ovat kiusallisessa tilanteessa: töitä ei ole, mutta työn tekijöitä riittää. Ylimääräiset ihmiset ovat taakka, jolle on löydettävä sijoituspaikka. Toistaiseksi paras ja käytetyin keino on laittaa työttömät ja aikuistuva nuoriso istumaan koulun penkille. Koulutuksella vähennetään työvoiman tarjontaa ja järjestetään kansalaisille tekemistä. Mitä useampi ikäluokka on koulutuksessa, sitä vähemmän on työttömiä. Myös työlliset pysyvät tyytyväisinä; koulutusta kun pidetään hyödyllisempänä kuin työttömyyttä eli "joutenoloa". Tämä näkemys on viime aikoina saanut paitsi valtiovallan, myös viestimien hyväksynnän. "Pakko-oppikin on parempaa kuin laiskottelu", todetaan maamme suurimmassa päivälehdessä (HS. 21. 2. 1996). Myös opetusviranomaiset suosittelevat työttömien kouluttamista (KM 1995:13, 11).
\end{abstract}

Yhdysvalloissa koulutusta käytetään ghetto-alueiden rauhoittamiseen. Nuoret, lähinnä neekerit ja latinot, varastoidaan kouluihin, jotta he ovat pois kaduilta (ks. Kozol 1992; Wacquant 1992). Koulutuksen sosiaalipoliittinen tehtävä on alkanut korostua myös Suomessa. Kriisitilanteissa hallinnon toimet saavat usein alkuperäisestä ja julkilausutusta tarkoituksestaan poikkeavan merkityksen. Aiemmin lapset laitettiin kouluun, jotta vanhemmat pääsivät töihin. Nyt koulutetaan sekä vanhempia että lapsia; tosin lapsiakin alettiin kouluttaa vasta sen jälkeen, kun lapsityövoimaa ei tuottavuussyistä enää tarvittu (Rahikainen 1996). Koulutuspolitiikka on paradoksaalisessa tilanteessa: kouluttaa pitää yhä enemmän, vaikka työtä on vähemmän.

\section{TYÖVOIMAVARASTO}

\section{Ylimäärätyövoima säilöön}

Tässä yhteydessä en käsittele koulutukseen yleensä liitettyjä haittoja tai hyötyjä: eliittien vallan kierrätystäja uusintamista (Bourdieu 1977), pakottavaa sosiaalistamista (Foucault 1980), etuoikeutettujen asemien perustamista (Collins 1971; Weber 1978), inhimillisen pääoman tuottamista (ks. Cohn \& Geske 1990) tai työvoiman suodatusta ja valikointia. Tarkastelen koulutuksen yhä näkyvämpää roolia "joutilaiden" kansalaisten varastona. Varastointihypoteesi perustuu epäilyyn, että pitkä koulutusaika olisi jotenkin välttämätöntä työelämän kannalta. Hypoteesi ei tarkoita sitä, ettei koulutus tuottaisi tiedollisia tai taidollisia ominaisuuksia. Sisällöstä riippumatta koulutusta voidaan käyttää varastointiin, sillä se varastoi aina työvoimaa muotonsa vuoksi. (Jolkkonen 1987, 66-67.)

Paci (1977) on esittänyt varastointihypoteesia tukevan uusmarxilaisen tulkintansa suhteellisesta liikaväestöstä: koulutuksella tuotetaan "ylimääräistä" työvoimaa, joka työskentelee julkisella sektorilla (ks. Broady 1991, 66; Hirsch 1985; Väherva 1983, 103; vrt. Marx 1948, 454-455). Koulutus sekä varastoi että tuottaa ylimääräistä työvoimaa.

\section{Varasto ratkaisuna työmarkkinoiden jäykkyyteen}

Jolkkosen (1987, 45-47) mukaan 1970-luvun puolivälin työvoimapolitiikassa alettiin kiinnittää huomiota joustamattomaan työvoimatarjontaan. Koulutusta pidettiin ratkaisuna työvoimarkkinoiden jäykkyyteen. 
Mutta pelkkä joustavuus ei aina riitä. Työvoiman rakenteen ohella myös sen määrä alkoi kiinnostaa työvoimaviranomaisia, ja 1970-luvun lopulla työvoimapolitiikan keinoksi oivallettiin ja hyväksyttiin työvoiman tarjonnan supistaminen koulutuksella (ks. Koistinen 1983, 38-42). Tuon ajan päättäjillä oli myös se "tarjontaetu", että työn perässä lähdettiin ulkomaille, lähinnä Ruotsiin. Rakennemuutoksista on selvitty muuttolaisuudella. Enää se ei onnistu.

Suomessa hyvinvointivaltion takaamat edut lisäävät työvoiman tarjontaa ja tekevät "täystyöllisyyden" saavuttamisen äärimmäisen hankalaksi. Sosiaali- ja palkkaturvajärjestelmästä hyötymisen ehtona kun on työvoiman tarjoaminen. Tarjontaa lisää vielä se, että naiset ja miehet kuuluvat tasa-arvoisesti työvoimaan. Kotirouvia ei juuri ole. Työttömyyden lisääntyessä tasa-arvosta ja työehdoista joudutaan ainakin osittain sopimaan uudestaan, varoittaa Beck $(1992,120)$. Hän toteaa naisten kotityön merkitsevän (Saksassa) massatyöttömyyden oloissa sitä, että vallitsevat roolit ja velvollisuudet säilyvät entistä sitkeämmin (Beckin kirjoittaessa kirjaansa 1980-luvulla Saksan työttömyysaste oli reilusti alle kymmenen prosenttia; nyt se on hieman yli). Miehet elättävät perheen ja naiset pitävät huolen kotitöistä ja lapsista.

Tasa-arvoinen työhön osallistuminen on Suomessa jo saavutettu, eikä siitä luopuminen liene todennäköistä. Täysipäiväiselle työnteolle tai työttömyydelle ei ole muita vaihtoehtoja kuin koulutus, mikäli mielii jostain rahaa saada. Vaihtoehtojen puutetta lisää se, että työehtosopimukset pitävät huolen vähimmäispalkoista ja työajoista. Toki tämä estää mcdonalds-proletariaatin synnyn, mutta samalla työttömyys lisääntyy (ks. Lash 1995). Pienemmät palkat eivät tosin välttämättä työllisyyteen vaikuta, jos työttömyyskorvaukset säilyvät ennallaan. Ay-liikkeelle ja työntekijöille ei palkanalennuksia tai työajan lyhennyksiä sovi esittää, sillä ne merkitsevät heidän asemansa huononemista. Myös ansiosidonnaisista korvauksista pidetään tiukasti kiinni. Tästä huolimatta Suomi on Euroopan edelläkävijä työllisyys- ja yhteiskuntapolitiikan toteuttajana, toteaa työelämän tutkija Antti Kasvio. Erityisesti ay-liike on ottanut vastuuta työllisyydestä. Vienti vetää, korot ja inflaatio ovat alhaiset ja taloustilanne on muutenkin vakaa, kehuu Kasvio. (Kansan Uutiset 1.3.1996.)

Beck (1992) arvelee ay-liikkeen roolin olevan täysin päinvastainen. Esimerkiksi työajan jakaminen ei tuo lisää työtä, vaan useammalle "vajaatyöllisyyttä" (underemployment), joten ay-liikkeen on pakko vastustaa sitä. Vajaatyöllisyydessä työnteko on joko määrä- tai osa-aikaista. Näin on Euroopassa osittain käynytkin (EU 95). Työmarkkinat pluralisoituvat, eli yhtenäisiä markkinoita tai yhteisiä sopimuksia ei ole, vaan työllisyyttä ohjaa kysyntä ja tarjonta. Tämä vähentää ay-liikkeen valtaa ja antaa työnantajille mahdollisuuden hyötyä liiallisesta työvoimasta. Niinpä ainoa ay-liikkeen hyväksymä keino työtuntien jakamiseksi on eläkeiän alentaminen ja koulutuksen pidentäminen. (Beck 1992, 143-146.)

\section{Varasto valvonnan välineenä}

Työmarkkinoiden ristiriitojen vuoksi varastointihypoteesi on hyvä lähtökohta koulutus- ja työvoimapolitiikan tutkimiseen. Siinä ei tosin oteta huomioon koulutuksen toista tärkeää varastoimitehtävää: koulutusta valvottuna varastona. Työttömille ja nuorille tarjotaan koulutusta, koska näin heidän toimeliaisuuttaan voidaan valvoa. Hirsch (1985) ja Foucault (1980; ks. Deleuze 1995) kirjoittavat yksilöiden tarkkailusta ja valvonnasta, kun taas Beck tahollaan huomauttaa kyseessä olevan yksilöiden "elämänkaaren" ohjailun. Erilaiset rajoitukset ja määritykset (esimerkiksi ikä) ohjaavat yksilöä koulutukseen, työelämään ja eläkkeelle. Yksilöllistyminen on johtanut tähän "markkinoiden" ja instituutioiden ulkoiseen valvontaan ja ohjailuun, toteaa Beck. (1992, 132.) Koulutuksella on työvoimapolitiikan kannalta siis ainakin kaksi tarkoitusta: a) se ohjaa työvoiman tarjontaa ja b) samalla kansalaisia kyetään valvomaan.

Valvontatehtävä on yhteiskunnan kannalta erityisen tärkeää, mikäli työttömien määrä paisuu liian suureksi. On sekä kansalaisten että yhteiskunnan kannalta helpompaa, jos työttömien joukot saadaan opiskelemaan pelkän oleskelun sijaan. Kun työttömät pannaan koulutukseen, hallinto tietää missä he ovat ja mitä tekevät. Kansalaisten olo taas helpottuu, koska työttömätkin täyttävät luterilaisuuteen kuuluvan työn velvollisuutensa hankkiessaan korvauksensa opiskelulla. 


\section{Kysyntä muuttuu tarjonnaksi}

Hallitus on varsin näkyvästi laajentanut koulutusmahdollisuuksia, lisännyt aloituspaikkojen määrää ja tiukentanut työttömyyskorvausten myöntämisen perusteita, jotta toimettomuus ei lisääntyisi ja tilastot näyttäisivät edes jotenkin siedettäviltä. Kaikki tämä on tapahtunut varsin lyhyen ajan kuluessa 1990-luvulla.

Koulutusta käytettiin työttömyyden hoitokeinona jo 1970-luvun lopussa. Tuolloin perustettiin työvoiman kysyntä- ja tarjontatoimikunta. Se piti koulutuspolitiikkaa tärkeimpänä keinona työvoiman kysynnän ja tarjonnan sopeuttamiseksi. Eräs keino oli 10-luokka, joka suunniteltiin niille nuorille, jotka hyvinä aikoina olisivat menneet töihin (10-luokan perustamisvaiheista ks. esimerkiksi Silvennoinen 1993). Muita 1970-luvun varastointikeinoja olivat: väliaikainen ammattikoulu, koulutusaikojen pidentäminen ja aikuiskoulutus. Suurin osa työvoiman tarjonnan määrään vaikuttavasta aikuiskoulutuksesta oli työllisyyskoulutusta. (KM 1979:42.)

Työllisyyskoulutus on sittemmin muuttunut "työvoimapoliittiseksi aikuiskoulutukseksi". Työllisyyskoulutus-nimike kun "korostaa opiskelijan kannalta epäolennaista koulutuksen piirrettä", toteaa kurssikeskustoimikunta (KM 1988:34). Tuo epäolennainen piirre voidaan hyvin kuvitella työvoiman varastoinniksi. Tämän vuoksi "työllisyyskoulutuksen yhteyttä työllisyyden hoitoon ei ole tarpeen korostaa" (emt.). Kyse oli ennen muuta koulutuksen arvostuksesta. (Ks. Silvennoinen 1992, 100-101.)

Työllisyyden hoito ei 1990-luvulla ole merkittävästi muuttunut, Koulutusta on tosin laajennettu uusille aloille ja aloituspaikkoja on lisätty, eli varastosta on tehty aiempaa suurempi. Vielä 1980-luvun lopulla koulutuksella oli merkitystä vain osaamisen ja tiedon lisääjänä. Pahimmat ajateltavissa olevat kriisit olivat rakennemuutos ja ympäristöongelmat. Rakennemuutoskin nähtiin vain vaiheittaiseksi siirtymiseksi tietoyhteiskuntaan. Kriisien aiheuttamien sosiaalisten ongelmien ja muiden haitallisten vaikutuksien torjumiseksi tarvittiin koulutusta, koska sillä oletettiin olevan perinteitä kansallisen kulttuurin vahvistamisessa. (KM 1988:28.)

Työttömyyttä ei pidetty suurena ongelmana. Ongelma oli pikemmin päinvastainen: koulutetulle väelle ennustettiin tarjonnan ylittävää kysyntää. jo tuolloin puhuttiin jatkuvan koulutuksen periaatteesta, josta myöhemmin tuli osa virallista liturgiaa. Koulutuksen tuli vastata työelämän tarpeita. Nousukauden koulutussuunnittelu perustui taloudellisen kasvun odotuksiin. Tarjonta päätettiin sopeuttaa kysyntään. "Uuden työvoiman tarvetta ei voida tyydyttää kuten aikaisemmin työmarkkinoille tulevalla nuorella työvoimalla. Tarvitaan yhä iäkkäämpien henkilöiden kouluttamista uusiin ja entistä vaativampiin tehtäviin", päätteli hallitus vuonna 1990 (VN 1990). Mitä nämä tehtävät olivat, sitä ei määritelty. Puhuttiin kansainvälisyydestä, tietotekniikasta ja työelämän muutoksista. Koulutustarve perustui vuoden 1988 arvioihin (ks. KM 1988:28). Kuten nyt tiedämme, kysyntää ei yhtäkkiä ollutkaan ja työvoimaa oli liiankin runsaasti tarjolla. Maamme joutui laskusuhdanteeseen, ja koulutustarvetta katsottiin lama-ajan valossa.

Jos vaihtoehtona on työttömyys tai koulutus, niin moni valitsee mieluummin jälkimmäisen. Erityisesti nuoret ovat halukkaita vaihtamaan työttömyyden koulutuspaikkaan (ks. esim. KM 1993:38; Koistinen 1994, 20). Opiskelijoiden määrä lisääntyi 80 000:lla 1990-luvun alkupuolella. Lisäys selittyy lähinnä ammatillisen koulutuksen täyttöasteen kasvulla. (KM 1993: 38, 50-51.) Koulutuksesta tuli ratkaisu nuorisotyöttömyyteen, koska lisäpaikat vaikuttivat työllisyyteen välittömästi. (KM 1993:38, 73-81.)

Koulutustarve on jälleen jouduttu arvioimaan uusiksi. Arviointia ei enää tehdä kysynnän tai nuorisotyöttömyyden vaan välttämättömyyden perusteella, sillä massatyöttömyyden vähentämiseksi tarvitaan käyttöön kaikki keinot. Opetusministeriö ehdottaa kehittämissuunnitelmassaan aloituspaikkoja lisättäväksi siten, että kaikille peruskoulun päättäville voidaan tarjota koulutuspaikka. Noin 60-65 prosentille koulutus on korkeakoulutasoista. Vuosina 1996-1998 ammatillisen koulutuksen tarjontaa lisätään 9000 paikalla 
vuodessa. Vuodesta 1997 alkaen aikuiskoulutuksen paikkoja lisätään 10000 - 20 000:1la. Vuodesta 1998 lähtien lisäystä on yhteensä 25000 vuosiopiskelijapaikkaa enemmän kuin vuonna 1995. (OPM 23.11.1995; St 1995). Tarjonnan lisäksi myös paikkojen täyttöä tehostetaan (Jussila 1996; St 1995).

Vuonna 1988 arvioitiin, että koulutusta tarvitaan vuoden 2000 työvoimatarpeeseen 104360 aloituspaikan verran: 78000 paikkaa nuorisolle ja 26360 paikkaa aikuisille. Vuoteen 1995 mennessä tarve lisääntyi selvästi; vuosituhannen vaihteessa tarvitaan yhteensä 150200 aloituspaikkaa. Niistä 113500 on varattu nuorisolle ja 36700 aikuisväestölle. Kuluvan vuosikymmenen loppuun tarvitaan vuosittain 167000 paikkaa. (KM 1988:28; KM 1995:13; OPM 23.11.1995.)

Samaan aikaan on lisätty myös työllisyyskoulutusta. Näyttää siis siltä, että työelämän tarpeesta lähtevä koulutussuunnittelu on viimeistään 1990-luvulla muuttunut kansalaisten ja työvoiman varastoinniksi. Työllisyysohjelmassa mainitaan, että 1990-luvulla on säästöistä huolimatta voitu lisätä koulutuksen tarjontaa vuosina 1990-1994 kaikkiaan 22 prosentilla eli lähes 80000 peruskoulutuksen opiskelijalla. Tutkintoon johtavassa koulutuksessa on vuonna 1996 kaikkiaan 330000 henkilöä. Paremminkin voisi toki olla. Säästämisen vuoksi koulutus ei ole ollut työttömyyden vaihtoehto siinä määrin kuin sen tulisi olla, todetaan työministeriössä (TM 1996:130).

Koulutustarjonnan lisääminen ei enää perustu pelkkään hyvään tahtoon ja tasa-arvoisen koulutuksen periaatteeseen. Niitä on täydennetty pakottein. Hallituksen työllistämiskeinot alkavat tällä erää olla vähissä, joten työttömiä joudutaan kouluttamaan väkisin. Sivistysvaltiossa täysi-ikäisiä ei voi sulkea koululaitokseen, mutta kun vaihtoehtoja ei tarjota, voidaan hyvinkin puhua pakosta. Jos jatkokoulutus ei maistu, ovat vailla ammattia olevan työttömän nuoren vaihtoehdot vähissä. Alle 20-vuotiaille ammattikouluttamattomille ei enää makseta työmarkkinatukea (ikäraja nostetaan 25 vuoteen 1997). Sen sijaan heidät ohjataan ammatillisiin opintoihin tai työharjoitteluun. (HE 172/1995.) Käytännössä oppivelvollisuus siis tarkoittaa vähintään 11 vuoden opintoja.

Tässä yhteydessä palaamme jälleen Beckin (1992) näkemykseen työmarkkinoiden muutoksesta ja Kasvion havaitsemaan ay-liikkeen rooliin työllisyystalkoissa. Nuoriso koulutetaan pakolla, koska heillä ei ole keinoja vastustaa "virallista näkemystä". Hallinto ei rohkene ehdottaa, että kaikkien vailla ammatillista tutkintoa olevien työttömien tulisi hakeutua oppiin ennen korvauksien maksatusta. Voi vain kuvitella minkä metelin ay-liike ja työtön aikuisväestö ehdotuksesta nostaisi. Vuonna 1993 ainoastaan perusasteen suorittaneita työttömiä aikuisia (yli 24 vuotiaita) oli kolmannes (145 000) kaikista työttömistä. "Kouluttamattomia" nuoria (15-24 vuotiaita) oli vajaa kymmenes (36 000). (Tilastokeskus: Työmarkkinat 1995:7.)

Ilmeisesti väestöä tullaan jatkossa kouluttamaan yhä enemmän ja koulutusta ruvetaan "suosittelemaan"; jo nyt ammattikouluttamaton joutuu odottamaan työttömyyskorvaustaan kauemmin kuin koulutettu. Ensimmäistä kertaa työmarkkinoille tulevan ja vailla ammatillista koulutusta olevan odotusaika piteni kolmesta kuukaudesta viiteen kuukauteen. Käytännössä uusi säännös koskee yli 20 vuotiaita, joilla ei ole ammatillista koulutusta. (HE 172/1995.)

Kuviosta 1 näkyy, miten koulutustutkinto on 1990-luvulla alkanut kiinnostaa yhä useampaa. Oikeastaan vain korkeakoulutus on tasaisesti lisännyt kiinnostavuuttaan myös nousukaudella. Tämä johtuu kyseisen väylän tarjoamien tutkintojen haluttavuudesta ja ylioppilaiden suuresta määrästä. Hakijoita on aina ollut enemmän kuin paikkoja tarjolla. Muita tutkintoja ei arvosteta samassa määrin, joten niitä ei myöskään suoriteta yhtä innokkaasti. Hyvinä aikoina töihin pääsi ilman tutkintoakin. Laman myötä tuotantoa on jouduttu useilla aloilla supistamaan ja tuottavuutta on padottu kouluihin. 


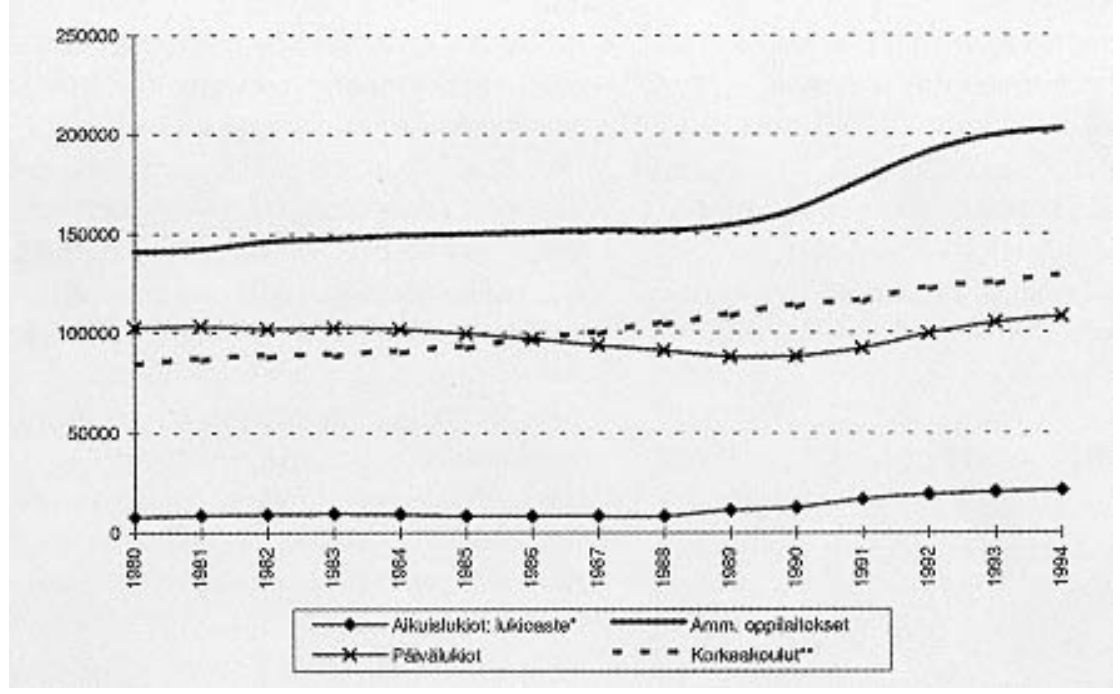

KUVIO 1. Tutkintoa suorittavat opiskelijat 1980-1994

*Vuodesta 1989 lähtien aineopiskelijat ovat mukana opiskelijamäärissä **Vuosien 1980-1992 luvussa ovat mukana vain syyslukukaudella aloittaneet. Lähde: Tilastokeskus.

\section{Lisääntyykö työllisyyskoulutuksella?}

Työttömälle aikuisväestölle järjestetään työllisyyskoulutusta. Siihen liittyy kuitenkin enemmän mielikuva pakollisesta "hätäavusta" kuin kunnon koulutuksesta. Työllisyyskursseja pidetään usein työttömien "päivähoitona" ja työmarkkinapelissä epäonnistuneiden vaihtoehtona. Tämä kuva elää yhä, vaikka entistä useammat eri sosioekonomisista ryhmistä osallistuvat koulutukseen. Kuten Silvennoinen (1993) toteaa, vanhasta "rupusakin" kouluttajan imagosta on vaikea päästä eroon.

Imago-ongelmasta huolimatta työllisyyskoulutus on laman myötä alkanut kiinnostaa useita työttömiä. Vähäisin syy ei liene se, että työttömyysturvaa nauttivan on osallistuttava työvoimaviranomaisen osoittamaan koulutukseen. Koulutusvelvollisuus ei aiemmin ole koskenut yli 50-vuotiaita, mutta "tulevaisuudessa tarve uudelleen koulutukseen tulee kasvamaan", joten ei ole mitään perustetta sille, että yli 50-vuotiaat voivat kieltäytyä koulutuksesta (HE 359/1992). Tulevaisuuden tarve on läsnä jo nykyisyydessä, ja työttömyystilastot kertovat aikuistenkin "koulutustarpeesta" varsin koruttomasti.

Toki työllisyyskoulutus on monille pakon sijasta tervetullut vaihtoehto joutavalle olemiselle tai peruspäivärahan saamiselle. Onhan työllisyyskoulutus eräs keino pitkittää ansiosidonnaisen päivärahan maksukautta. Lisäksi koulutukseen osallistuva on tietyin ehdoin oikeutettu saamaan verotonta koulutusrahaa 1100 markkaa kuukaudessa.

\section{Koulutusta järjestäville erilaisille kurssikeskuksille ja yksityisille yrittäjille} työllisyyskoulutus on keino työllistää Itsensä ja ansaita rahaa. Työllisyyskoulutuksen järjestämiselle ja koulutukseen osallistumiselle on siis perusteita.

Koulutettujen työllistyminen ei kuitenkaan perusteeksi käy. Räisäsen $(1995,38)$ tutkimus nimittäin osoittaa, että työllisyyskoulutus on epäonnistunut koulutettujen työllistymisessä (ks. Hietala 1995; Santamäki-Vuori 1996). Tilanne on paradoksaalinen, sillä tulosten mukaan työllisyyskoulutukseen osallistuminen merkitsee suurempaa riskiä jäädä työttömäksi kuin työnhaku ilman koulutusta. Aivan näin huono todellinen tilanne ei varmastikaan ole. Työllisyyskoulutuksessa olevat saattavat olla valikoituneempaa joukkoa kuin muut työnhakijat. Työllisyyskoulutuksen tehottomuutta ei kuitenkaan voi kokonaan selittää koulutuksessa olevien työhistorialla, sen puutteella tai muilla taustatekijöillä. Räisänen tyytyy toteamaan, että työllisyyskoulutuksen perustavanlaatuinen järkevyys on taattu vaikeissakin lamaoloissa. Artikkelini lopuksi pohdin lyhyesti tätä "järkevyyttä". 


\section{Mitä maksaa?}

Ruotsi on sijoittanut työttömien kouluttamiseen kaksi kertaa Suomea enemmän rahaa. Kysymys on pitkälti hallitusten valinnasta: joko lisätä rahoitusta tai työttömyyttä. Ruotsi on harjoittanut aktiivista työvoimapolitiikkaa ja onnistunut pitämään työttömyysasteensa pienempänä kuin Suomi (Koistinen 1994). Ekonomistit ihmettelevät Ruotsin taipumusta panostaa yhä enemmän työllisyyskoulutukseen, vaikka koulutuksen vaikuttavuus (työllistymisen todennäköisyys) on selvästi laskenut, kirjoittaa Hietala (1995). Hänen mielestään ilmiö voi saada selityksensä poliittisesta taloustieteestä: työlliset eivät halua, että työttömät tulevat kilpailemaan työpaikoista, joten he kannattavat tehotonta varastointia. Näin työlliset voivat vaatia suurempia palkankorotuksia vailla pelkoa kilpailusta. Ruotsissa ay-liike ei suostunut liittämään yritysharjoittelua työllisyyskoulutukseen, mikä osaltaan tukee tätä selitystä. Ruotsissa ilmeisesti pelättiin, että koulutettavat joko tekisivät töitä halvemmalla tai peräti työllistyisivät koulutuksensa jälkeen.

Työllisyyskoulutuksen määrällinen kehitys on Suomessa ollut nopeaa. Työvoimapolitiikassa ei 1960-luvulla koulutusta juuri työttömyyden hoitoon käytetty, ja tämä näkyy myös koulutusluvuissa: koulutettavia oli enimmilläänkin muutama tuhat kuukausittain. Kuten jo todettiin, 1970-luvun puolivälissä keskityttiin työvoiman määrän ohjailuun: koulutettavia oli yli 10000 kuukaudessa. Koulutettavien kuukausittainen määrä vakiintui 1980-luvulla noin 15 000:een. Vasta lama herätti työvoimaviranomaiset ja kouluttajat: 1990-luvun lamavuosina työllisyyskoulutuksessa on kuukausittain ollut keskimäärin 30000 suomalaista. Hakijoita on vuosittain ollut noin 100000 ja suorittaneita noin 60 000. (Silvennoinen 1992, 103; TM 1995:3.) Vuosina 1991-1994 koulutuksen suorittaneiden keskimääräinen koulutusaika oli neljä kuukautta.

Koulutus maksaa 28000 markkaa suorittanutta kohti. Yhden suoritetun koulutuskuukauden hinta on 7000 markkaa. Kustannukset on laskettu työvoimapoliittisen aikuiskoulutuksen osalta valtion tulo- ja menoarvioista. Työllisyyden hoidon erityistoimenpiteistä työllisyyskoulutus on selvästi kalleinta. Se on jopa kolmanneksen kalliimpaa kuin muut erityistoimenpiteet (starttiraha, työllistäminen, valtion työtehtävät, työllistämistuet yms.). (Hietala 1992, 4.) Puutteistaan huolimatta työllisyyskoulutusta pidetään tehokkaan ratkaisuna työttömyyteen: vuodesta 1990 työllisyyskoulutukseen varatut määrärahat ovat lähes viisinkertaistuneet ja aikuiskoulutuksen määrärahat lähes kaksinkertaistuneet. Vuonna 1996 näihin käytetään rahaa yhteensä reilu neljä miljardia markkaa.

Työministeriössä on laskettu yhden koulutuspäivän hinnaksi vuosina 1991-1994 reilu 130 markkaa. Myös muu aikuiskoulutus on ainakin tietyin osin työvoimapoliittista, joten sen mukaan ottaminen olisi perusteltua.

\section{Onkin syytä kysyä, onko työllisyyskoulutus enää kohtuullista, jos se ei palvele ensisijaista tarkoitustaan eli työllistymistä.}

Lähes 7000 markan kuukausittaisilla lisätuloilla työtön saisi paljon muutakin kuin todistuksen kurssista. Lisäksi kansantalouteen tulisi kovin kaivattua yksityistä kulutuskysyntää. Harrastukseksi työvoimapoliittinen koulutus on melko kallista. Toki kuluissa on koetettu säästää; tosin lähinnä osallistujien kustannuksella.

Vuonna 1992 luovuttiin työllisyyskoulutuksen lapsikorotuksista (HE 274/1992). Seuraavana vuonna työvoimapoliittisesta aikuiskoulutuksesta annettua lakia esitettiin muutettavaksi, jotta osallistujien ateria- ja matkakustannusten korvauksista voitaisiin luopua. Silloisilla koulutusmäärillä säästö arvioitiin noin 160 miljoonaksi markaksi vuodessa. Esitystä ei hyväksytty. (HE 240/1993.) Asiassa kävi päinvastoin: vuonna 1996 ylläpitokorvausta maksetaan myös niille koulutettaville, jotka saavat työmarkkinatukea. Kustannukset ovat 55 miljoonaa markkaa vuodessa. Työmarkkinatukeen liitetyt rajoitukset sinänsä - esimerkiksi alle 20-vuotiaiden "koulutuspakko" - säästävät työhallinnon rahoja noin 0,5 miljardia markkaa. (HE 172/1995.) 


\section{Miksi koulutuksesta tuli tarkkailtua varastointia?}

Työllisyyskoulutuksen määrä, kesto ja laatu on muuttunut. Ammattikouluttamattomille työttömille voitiin aiemmin tarjota "risusavottaa" ja ammattikursseja, mutta nyt samassa tilanteessa oleva keskiluokka ei siihen tyydy. Tarvitaan hienostuneempaa tekemistä. Myös nuoret ovat aiempaa vaativampia; koska ammattikoulutus ei kaikille kelpaa, täytyy (ammatti)korkeakoulutusta lisätä. Ammattikouluun pakotetaan ja korkeakouluun valitaan. Ylempi korkeakoulutus on toistaiseksi säilyttänyt yhteiskunnallisen arvostuksensa, eikä opintoihin ole tarvittu keppiä; pelkkä porkkana on riittänyt. Tiedekorkeakouluilla on puolellaan se etu, että koulutuksesta vastaava keskiluokka on suorittanut tutkintonsa yliopistossa. Oman tutkinnon devalvoiminen ei kannata, joten vain alemman kouluasteen ja ammattikorkeakoulutuksen tarjontaa lisätään merkittävästi. Aloituspaikkojen lisäyksen syynä lienee piilevä pelko kurin menetyksestä, "joutilaisuuden" aiheuttamasta moraalisesta rappiosta ja hallitsemattomasta väen paljoudesta, joka aiemmin saatiin sijoitettua tuotantoon ja laitoksiin. (ks. Foucault 1980.)

Koulutus myös tuottaa työtä. Esimerkiksi 10-luokkaa perustettaessa opettajat olivat varsin ilahtuneita lisääntyneistä työmahdollisuuksista (Naumanen 1990, 203; Silvennoinen 1993, 365). Mitä enemmän ihmisiä varastoidaan koulutukseen, sitä enemmän tarvitaan varastonhoitajia: suunnittelijoita, opettajia, tutkijoita, koulujen rakentajia ja kunnostajia, isännöitsijöitä, koulutoimenjohtajia ja keittiöhenkilökuntaa. Koulutus työllistää kaikkiaan noin 250 000, joista viidenneksellä on ylempi korkeakoulututkinto (Tilastokeskus).

Taulukossa 1 on esitetty "työikäisen paljouden" hallintaa Suomessa. Luvut kuvaavat sitä, miten opetusala (siitä palkkansa saavat ja opiskelijat) sitoo työvoimaa. Kyseessä on liikaväestön varastointi, kuten Paci (1977) asian sanoisi. Esitetyt luvut perustuvat siihen ajatukseen, että kaikki koulutuksessa olevat työikäiset ovat osa liikaväestöä; aivan kuten heidän opettajansakin ja muut opetusalan työllistämät. Varmastikaan asiat eivät näin todellisuudessa ole, vaan koulutus myös tuottaa päteviä työntekijöitä ja hyödyttää muutenkin työelämää.

TAULUKKO 1. Opetusalaan kuuluvasta työstä palkkansa saavat ja työikäiset opiskelijat 1994

\begin{tabular}{llll} 
Paljous & $\mathrm{N}$ & / työvoima* $^{*}$ & \%-työikäisestä väestöstä \\
& & & \\
\hline Opetusalaan kuuluva työ $^{2}$ & 215280 & 0.1 & 6 \\
Työikäiset opiskelijat $^{3}$ & 499625 & 0.2 & 14 \\
Yhteensä $^{714905}$ & 0.3 & 20
\end{tabular}

* Suhteessa työvoimaan: esim. opiskelijat / työvoima $=0.2$ tarkoittaa, että työikäisten opiskelijoiden määrä on viidennes työvoiman määrästä. Suhdeluku on pyöristetty yhdeksi desimaaliksi.

${ }^{1}$ Tilastokeskus: Väestö 1995:8.

${ }^{2}$ Laskettu vuoden 1990 väestölaskennan pitkittäistiedostosta; sotilas- suojelu- ja poliisialaa ei ole laskettu mukaan lukuihin

${ }^{3}$ Päivisin tutkintoa suorittavat ja 10-luokalla tai työllisyyskoulutuksessa olevat. Lähde: Tilastokeskus.

Viidennes työikäisestä väestöstä on varastoitu koulutussektoriin. Heidän määränsä on vajaa kolmannes työvoiman määrästä. Suhdeluku olisi suurempi, jos mukaan laskettaisiin aikuiskoulutuksessa olevat ja muut "kurssitettavat". Yksin opetusala työllistää vajaan kymmeneksen työvoimasta. Koulutukseen varastoidaan huomattava osa työikäisestä väestöstä.

Saksalaisten teoreetikkojen (Beck; Hirsch) näkemyksissä yksilöistä tehdään erilaisin valvonnan keinoin joista koulutus on ehkä tärkein - normalisoituja abstrakteja hahmoja, joilla on kuitenkin jäljellä myös omaa tahtoa. Heidät laitetaan ojennukseen, mutta tämä ei silti tukahduta "Minää". Englantilainen Nikolas Rose (1990; Rose \& Miller 1992) korostaa sosiaalisen etiikan merkitystä kansalaisten hallinnassa. Sosiaalipoliittisella hallinnolla yksilön, Minän, päähän iskostetaan yhteiskunnalliset velvoitteet. Niitä noudattamalla yksilöstä tulee yhteiskunnan kelpo jäsen. Saksalaisteoreetikot uskovat, että sosiaalisista 
pakoista huolimatta "Minä" on liian kova vastus yhteiskunnan rakenteille. Yksilö ei koskaan täysin hyväksy valtakoneiston haltuunottoa, vaan se tekee jatkuvaa vastarintaa perustamalla erilaisia alakulttuureja, teollisen yhteiskunnan vastarintaliikkeitä. (Ks. Beck 1992; Hirsch 1985, 155.)

Näin ei ole ainakaan Suomessa käynyt: alakulttuureja on kyllä syntynyt, mutta ne liittyvät teollisen yhteiskunnan tuottamaan kysyntään ja tarjontaan, kuten tavaroiden kulutukseen, koulutukseen, taiteeseen ja järjestötoimintaan yms. Myös Beckinsä lukenut Scott Lash (1995) pitää yksilöllistymistä ja erilaisia yhteisöjä tiettyjen kenttien tuotteina ja kulutuksena (vrt. Bourdieu 1984).

\section{Yhteisöissä ei ole tärkeää merkityksien pohtiminen tai vastarinta, vaan niiden} kuluttaminen. Ehkä työttömät ja nuoriso ovat juuri tästä syystä hyväksyneet koulutuksensa ja esittäneet harvoin kysymyksiä sen mielekkyydestä. Se on väline ja osa jokapäiväistä kulutusta.

Koulutus on ainakin toistaiseksi houkutellut nuorisoa ja miksei vanhempaakin väestöä, mutta voiko ammattiin valmistava koulu säilyttää uskottavuutensa, jos töitä ei riitä kaikille valmistuneille? Opetuksen kannalta ei liene syytä kouluttaa kaikkia oppilaita ammattiin, koska osalle riittäisi omien (oppimis)tarpeidensa tyydyttäminen: kielet, kirjallisuus, tietotekniikka, käsityöt ja kaikenlainen muu harrastaminen. Monimutkaiset opintokokonaisuudet merkitsevät osalle ainoastaan pitkää ja turhaa koulutusta. Tämä ei kiinnosta kaikkia ja tulee kalliiksi. Myöskään työelämä ei näillä näkymin tarvitse kuin pienen määrän alansa erikoisosaajia. Kun korkeakouluun haluava nuori "pakotetaan" ammattikouluun, hän saattaa viedä alalle haluavalta opiskelupaikan. Myös työttömille järjestetään kallista "ammatillista" koulutusta, vaikka osa heistä osallistuu siihen joko harrastusmielessä tai siksi, että ei menettäisi päivärahojaan.

\section{Opetus- ja työvoimaviranomaiset tosin luottavat tietoyhteiskunnan tuomiin työpaikkoihin, vaikka tutkimukset eivät asiaa vahvistakaan.}

Työ ei välttämättä muutu vaikeammaksi (Rumberger 1987), eikä edistynyt teknologia lisää työtä siinä määrin kuin luullaan (Johnson 1991).

Ilmeisesti koulutuksen tehtävänä on yhä varmistaa, että usko yhteiskuntaan säilyy. Opiskelijat odottavat koulutuksen tuovan töitä. Vaikka töitä ei heti saisikaan, takaa tutkinto yhteiskuntakelpoisuuden. Lisäksi koulutus on houkutteleva vaihtoehto parempien aikojen odotteluun (ks. Naumanen 1990, 203). Odotusaikaa on jatkuvasti pidennetty erilaisilla uudistuksilla, jotka samalla tekevät tutkinnoista haluttavampia -esimerkkinä vaikkapa ammattikorkeakoulu. Koulutukseen on uskottu siitä huolimatta, että arvojen, valmiuksien ja "sivistyksen" tuottajasta on entistä näkyvämmin tullut panoptinen järjestelmä, jonne väestöä varastoidaan valvottavaksi. Tässäkö piilee koulutuksen "perustavanlaatuinen järkevyys"?

Aivan lopuksi on syytä antaa yhteiskuntateoreetikko Jürgen Habermasille puheenvuoro: "Toinen teollinen vallankumous kohottaa työn tuottavuutta erittäin nopeasti ja vähentää ratkaisevasti yhteiskunnallisesti välttämätöntä työaikaa. Tämän vuoksi tarvitaan yhä absurdimpia toimenpiteitä, jotta ulkopuolelle suljettujen ja rajalle ahdistettujen kasvavaa joukkoa voitaisiin ylläpitää reservinä kapitalististen työmarkkinoiden normiksi kohottamalle täystyöllisyydelle - sen sijaan että toimeentulo ja sosiaalinen turvallisuus irrotettaisiin ammatissa toimimisesta ja lakkautettaisiin työmarkkinoiden fetisismi." (Habermas 1994, 45.) Habermasin mietteisiin palaan työn alla olevassa väitöskirjassani, jossa koulutuksen varastointifunktiota esitellään laajemmin. 


\section{Kirjallisuus}

Beck, Ulrich 1992. Risk Society - Towards a New Modernity. London: SAGE.

Bourdieu, Pierre 1977. Reproduction in education, society and culture. London: SAGE.

Bourdieu, Pierre 1984. Distinction: a social critique of the judgement of taste. USA: Harvard University Press.

Broady, Donald 1991. Piilo-opetussuunnitelma. Tampere: Vastapaino.

Collins, Randall 1971. Functional and conflict theories of educational stratification. American Sociological Review 36(12), 1002-1019.

Cohn, Elchan \& Geske, Terry G. 1990. Economics of education. USA: Pergamon Press.

Deleuze, Gilles 1995. Negotiations. New York: Columbia University Press.

EU 95 1995. Employment in Europe 95. Online edition.

Foucault, Michel (1980) Tarkkailla ja rangaista. Helsinki: Otava.

Habermas, Jürgen 1994. Järki ja kommunikaatio: tekstejä 1981-1989. Helsinki: Gaudeamus.

HE 106/1989. Hallituksen esitys eduskunnalle valtion tuloja menoarvioksi vuodelle 1990.

HE 117/1990. Hallituksen esitys eduskunnalle valtion tuloja menoarvioksi vuodelle 1991.

HE 57/1991. Hallituksen esitys eduskunnalle valtion tuloja menoarvioksi vuodelle 1992.

HE 122/1992 Hallituksen esitys eduskunnalle valtion talousarvioksi vuodelle 1993.

HE 274/1992. Laiksi työvoimapoliittisesta aikuiskoulutuksesta annetun lain muuttamisesta.

HE 240/1993. Laiksi työvoimapoliittisesta aikuiskoulutuksesta annetun lain muuttamisesta.

HE 359/1992. Hallituksen esitys laiksi työttömyysturvalain muuttamisesta.

HE 126/1993. Hallituksen esitys eduskunnalle valtion talousarvioksi vuodelle 1994.

HE 152/1994. Hallituksen esitys eduskunnalle valtion talousarvioksi vuodelle 1995.

HE 72/1995. Hallituksen esitys eduskunnalle valtion talousarvioksi vuodelle 1996

HE 172/1995. Hallituksen esitys eduskunnalle laiksi työmarkkinatuesta annetun lain muuttamisesta.

Hietala, Kari 1992. Työttömyyden kustannukset. Työpoliittinen aikakauskirja 3/1992.

Hietala, Kari 1995. Kritiikkiä Ruotsille-johtopäätöksiä Suomelle. Työpoliittinen aikakauskirja 4/1995.

Hirsch, Joachim 1985. Turvavaltio. Tampere: Vastapaino.

Johnson, Scott D 1991. Productivity, the workforce, and technology education. Journal of Tecbnology education 2 (2), online edition.

Jolkkonen, Ari 1987. Koulutuksen varastointihypoteesi. Joensuun yliopisto, Kasvatustieteiden tiedekunnan selosteita n:o 17. Joensuu.

KM 1988.-28. Väestön koulutus 2000. Koulutussuunnittelun neuvottelukunta.

KM 1988-34. Kurssikeskustoimikunnan mietintö.

KM 1993:38. Vaihtoehto työttömyydelle. Nuorisokansliapäällikkötyöryhmän raportti.

KM 1995:13. Elinikäinen oppiminen tietoyhteiskunnassa.

Koistinen, Pertti (1983) Työllisyyskriisi ja vaihtoehtoisen työvoimapolitiikan mahdollisuudet Helsinki: Tutkijaliitto.

Koistinen, Pertti 1994. Kilpailevia ratkaisuja työllisyyteen. Suomen ja Ruotsin työmarkkinoiden ja työvoimapolitiikan vertailua lamavuosina 1990-1994. Tampereen yliopiston sosiaalipolitiikan laitoksen sarja B, n:o 17. Tampere.

Kozol, Jonathan 1992. Savage inequalities: children in America's schools. USA: Harper Perennial. 
Lash, Scott 1995. Refleksiivisyys ja sen vastinparit: rakenne, estetiikka ja yhteisö. Teoksessa Beck, U., Giddens, A. \& Lash, S. Nykyajan jäljillä. Tampere: Vastapaino.

Marx, Karl 1948. Pääoma; osa I. Helsinki: Kansankulttuuri Oy.

Naumanen, Päivi (1990) Kansalaiskuva Suomessa. Kansalaista koskevat käsitykset opettajien ammattilehdissä 1880-luvulta 1980-luvulle. Koulutussosiologian tutkimusyksikön raportti 6. Turun yliopisto.

Opetusministeriö 1995. Koulutuksen ja korkeakouluissa harjoitettavan tutkimuksenkehittämissuunnitelma vuosille 1995-2000.

Paci, Massimo 1977. Education and the Capitalist Labor Market. Teoksessa Karabel, J. \& Halsey, A. H. (eds.). Power and Ideology in Education. New York: Oxford University Press.

Rahikainen, Marjatta 1996. Miksi lasten työnteko päättyi - ja miksi se alkoi uudestaan. Janus 4 (1), 22-38.

Rose, Nikolas \& Miller, Peter 1992. Poltical power beyond the State: problematics of government. The British Journal of Sociology 43 (2), 173-205.

Rose, Nikolas 1990. Governing the soul: the shaping of the private self. Routledge: London

Rumberger, Russet W. 1987. The Potential impact of new technologies on the skill requirements of future jobs in the United States. Teoksessa Burke, G. \& Rumberger, R. W.(eds.) The Future impact of technology on work and education. Great Britain: The Falmer Press.

Räisänen, Heikki 1995. Työvoimakoulutuksen tuloksellisuus: Työllisyys, ammatillisuus ja kohdentuminen. Työpoliittinen tutkimus 94. Työministeriö, Helsinki.

Santamäki-Vuori, Tuire 1996. Pitkäaikaistyöttömien työmarkkinakokemukset lamavuosina 1993-1994. Helsinki: Työministeriö.

Silvennoinen, Heikki (1992) Koulutus ja työmarkkinoilla pärjääminen. Koulutussosiologian tutkimuskeskuksen raportteja 9. Turun yliopisto.

Silvennoinen, Heikki 1993. Työvoimakoulutuksesta työmarkkinoille: suhdanteet ja sijoittuminen. Työpoliittinen aikakauskirja 2/1993.

Silvennoinen, Heikki 1993. Työllisyysluokat lamasta lamaan: 15 vuotta lisäopetusta peruskoulun 10. luokalla. Kasvatus 24 (4), 364-376.

St 1995. Suomen työllisyysohjelma 1996-1999. Työttömyyden puolittaminen.

Tilastokeskus 1987. Korkeakoulut 1985. Koulutus ja tutkimus 1987:2.

Tilastokeskus 1988. Ammatilliset oppilaitokset 1987. Koulutus ja tutkimus 1988:23.

Tilastokeskus 1995. Yleissivistävät oppilaitokset 1994. Koulutus 1995:6.

Tilastokeskus 1995. Ammatillisten oppilaitosten opiskelijat 1994. Koulutus 1995:9.

Tilastokeskus 1995. Korkeakoulut 1995. Koulutus 1995:14.

TM 1996:130. Työvoima 2010. Työministeriö.

Vaherva, Vaherva 1983. Koulutuksen vaikuttavuus. Jyväskylän yliopiston kasvatustieteen laitoksen julkaisuja A 1/1983. Jyväskylä.

Wacquant, Loïc. J. D. 1993. Amerikka toteutuneena dystopiana: sosiaalinen integraatio ja kaupunkipolitiikka. Tiede \& Edistys 12 (2), $143-151$.

Weber Max 1978. Economy and society; vol 2. University of California Press. 